\title{
Formal ratification of subseries for the Pleistocene Series of the Quaternary System
}

\author{
${ }^{1}$ Department of Earth Sciences, 1812 Sir Isaac Brock Way, Brock University, St. Catharines, Ontario L2S 3A1, Canada; *Corresponding author, \\ E-mail:mjhead@brocku.ca \\ ${ }^{2}$ Research School of Earth Sciences, The Australian National University, Acton, ACT, 2601, Australia \\ ${ }^{3}$ School of Geography, Geology and the Environment, University of Leicester, University Road, Leicester LE1 7RH, UK \\ ${ }^{4}$ Table 1
}

(Received: February 9, 2020; Revised accepted: September 8, 2020)

https://doi.org/10.18814/epiiugs/2020/020084

The Pleistocene Series/Epoch of the Quaternary System/Period has been divided unofficially into three subseries/subepochs since at least the 1870s. On $30^{\text {th }}$ January, 2020, the Executive Committee of the International Union of Geological Sciences ratified two proposals approved by the International Commission on Stratigraphy formalizing: 1) the Lower Pleistocene Subseries, comprising the Gelasian Stage and the superjacent Calabrian Stage, with a base defined by the GSSP for the Gelasian Stage, the Pleistocene Series, and the Quaternary System, and currently dated at $2.58 \mathrm{Ma}$; and 2) the term Upper Pleistocene, at the rank of subseries, with a base currently undefined but provisionally dated at $\sim 129 \mathrm{ka}$. Defining the Upper Pleistocene Subseries and its corresponding stage with a GSSP is in progress. The Middle Pleistocene Subseries is defined by the recently ratified GSSP for the Chibanian Stage currently dated at $0.774 \mathrm{Ma}$. These ratifications complete the official division of the Pleistocene into three subseries/ subepochs, in uniformity with the similarly subdivided Holocene Series/Epoch.

\section{Introduction}

The Pleistocene was first introduced by Charles Lyell as a substitute for his Newer Pliocene (Lyell, 1839, p. 621) although he did not embrace the term formally until 1873 (Lyell, 1873, p. 3-5; Head and Gibbard, 2015a). Only in 1985 was the Pleistocene formally defined as a series/epoch by a Global boundary Stratotype Section and Point (GSSP) at Vrica, Calabria, Italy (Aguirre and Pasini, 1985). Its base was subsequently lowered in 2009 to coincide with that of the Gelasian Stage/Age and Quaternary System/Period, defined by a GSSP at Monte San Nicola in Sicily, Italy, currently dated at $2.58 \mathrm{Ma}$ (Gibbard and Head, 2010).

The Pleistocene meanwhile has been subdivided informally into three parts since at least the 1870s (Head, 2020). The terms Lower, Middle, and Upper Pleistocene were used at the Second International Conference of l'Association pour l'Étude du Quaternaire européen (a forerunner of the International Union for Quaternary Research [INQUA] and its congresses) held in Leningrad, now Saint Petersburg, Russia in 1932 (Woldstedt, 1953). These positional terms were later used more formally in English by Zeuner $(1935,1945)$ and Hopwood (1935), as noted by Pillans and Gibbard (2012). Beginning effectively with the Leningrad Conference, the former USSR and Russia established a somewhat different scheme, with the Eopleistocene equivalent to the Gelasian and Calabrian, and the Neopleistocene equivalent to the Middle and Upper Pleistocene. The Neopleistocene itself has lower, middle and upper subdivisions, and the Upper Neopleistocene is exactly equivalent to the Upper Pleistocene (e.g., Tesakov et al., 2015; Head and Gibbard, 2015a and references therein). Nonetheless, the terms Lower, Middle and Upper have a long history of use in chronostratigraphically subdividing the Pleistocene in the former USSR and Russia (Gromov, 1939; Nikiforova, 1987; Gaudenyi et al., 2014).

Although these positional terms have been used regularly for more than a century in the Quaternary literature, where they are treated as chronostratigraphic/geochronologic subdivisions, the formal rank of subseries/subepoch was approved by the International Union of Geological Sciences (IUGS) only in June 2018, specifically with respect to the subdivision of the Holocene. The Holocene is now officially subdivided into Greenlandian, Northgrippian, and Meghalayan stages/ ages and their corresponding Lower/Early, Middle, and Upper/Late Holocene subseries/subepochs (Walker et al., 2018, 2019; Fig. 1).

Aubry (2016) and Head et al. (2017) presented a multifaceted case for adopting the subseries/subepoch as a formal rank within the Cenozoic. However, the primary reasoning for Holocene subseries derives from the universal use of geochronology in Holocene stratigraphy, facilitated by an array of geochronometric methods that are considerably more reliable and precise than classical approaches to stratigraphic correlation. Holocene stratigraphic records are accordingly plotted routinely against time rather than depth, and the positional terms Early, Middle and Late are therefore natural in this context (Head et al., 2017; 


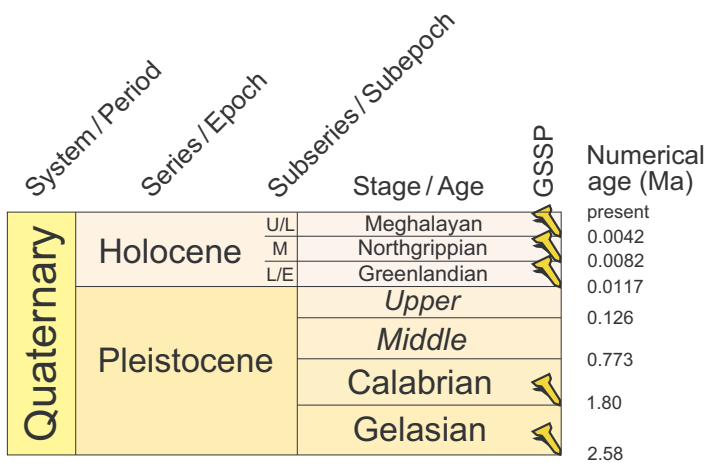

a) Previously ratified scheme

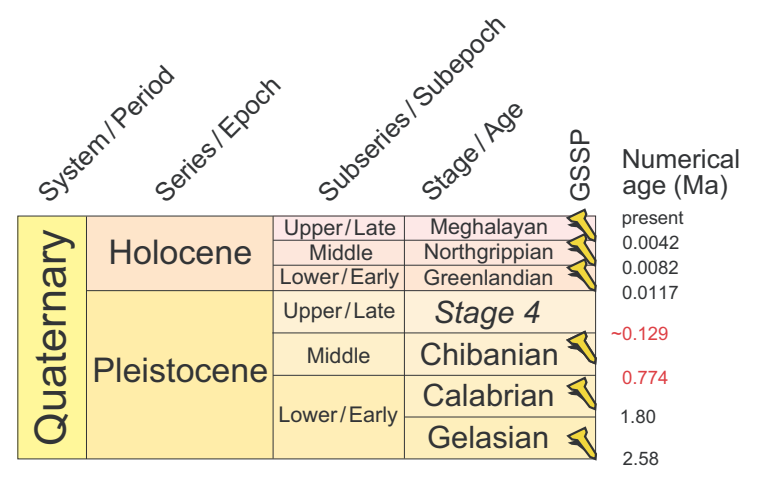

b) Presently ratified scheme

Figure 1. Quaternary interval of the ICS International Chronostratigraphic Chart showing: a) the scheme as of May, 2019, and b) the now ratified scheme. The previous age for the base of the Middle Pleistocene $(0.773 \mathrm{Ma})$ is based on that of the Matuyama-Brunhes boundary whereas its current age $(0.774 \mathrm{Ma})$ is that of the Chiba GSSP which occurs $1.1 \mathrm{~m}$ below this boundary. The current provisional age for the base of the Upper Pleistocene ( 0.129 Ma) reflects a sharp rise in temperatures just before peak warming during the Last Interglacial (Head, 2019). See Table 2 and text for colour coding.

Head, 2019; Walker et al., 2018, 2019).

Pleistocene subdivision lends itself to similar justification, such as where continuously deposited marine deposits containing proxies for environmental change are calibrated to an insolation curve that is orbitally derived and hence numerically calculated. Such tuned records are accordingly displayed in years, or thousands of years, before present. They are critical to the numerical calibration of the Global boundary Stratotype Sections and Points (GSSPs) for the Gelasian, Calabrian, and Chibanian stages/ages of the Pleistocene.

Therefore, in order to formalize terms already in long use within the Quaternary community, and to bring Pleistocene subseries/subepoch terminology in line with that of the Holocene, a set of proposals was brought forward to the International Commission on Stratigraphy's (ICS) Subcommission on Quaternary Stratigraphy (SQS) and then to the voting membership of the International Commission on Stratigraphy.

\section{Proposals and results of SQS and ICS voting}

The proposals are given below. Voting within SQS, comprising 22 voting members (one member did not return their ballot form), concluded on November 5, 2018 (Table 1). Voting within ICS, comprising 19 voting members (all returning their ballot forms), concluded on $27^{\text {th }}$ November, 2019.

Proposal 1: to formalize the Lower/Early Pleistocene Subseries/ Subepoch, comprising the Gelasian Stage/Age and the superjacent Calabrian Stage/Age, with a GSSP corresponding to that of the Gelasian Stage, the Pleistocene Series, and the Quaternary System. Age: $2.58 \mathrm{Ma}$. SQS vote: 20 in favour, 1 against, $95 \%$ supermajority. ICS vote: 17 in favour, 2 against, $89.5 \%$ supermajority. There were no abstentions in either vote. The proposal was carried by supermajority.

Proposal 2: to formalize the terms Upper/Late Pleistocene with a base currently undefined but provisionally dated at $\sim 129 \mathrm{ka}$. SQS vote: 19 in favour, 2 against, 90\% supermajority. ICS vote: 17 in favour, 2 against, $89.5 \%$ supermajority. There were no abstentions in either vote. The proposal was carried by supermajority.

A third proposal, to formalize (but not define) the term Middle Pleisto- cene, had been included in SQS voting and received 20 votes in favour, 1 against, with no abstentions, and hence carried with a $95 \%$ supermajority. However, SQS delayed submitting to ICS its set of subseries proposals so that a separate proposal on the Chibanian Stage and Middle Pleistocene Subseries (Suganuma et al., this issue) could be considered simultaneously by ICS. This rendered the third (Middle Pleistocene) proposal redundant, and it was not submitted to ICS for voting.

\section{Ratification of Proposals}

On $30^{\text {th }}$ January, 2020, the Executive Committee of the International Union of Geological Societies ratified both Lower and Upper Pleistocene subseries/subepoch proposals. The separate proposal to define the Chibanian Stage and Middle Pleistocene Subseries/Subepoch (Suganuma et al., this issue) had meanwhile been ratified on $17^{\text {th }} \mathrm{Jan}$ uary, 2020. These ratifications together completed formal subdivision of the Pleistocene into the desired Lower/Early, Middle, and Upper/ Late subseries/subepochs.

\section{Subdivision of the Pleistocene Series/Epoch}

Ratification formalizes subseries/subepoch terms already used widely for the Pleistocene. The new definitions of these terms, and the history behind them, are discussed below.

\section{Lower/Early Pleistocene Subseries/Subepoch}

The Lower/Early Pleistocene Subseries/Subepoch is defined by the GSSP for the Gelasian Stage/Age, the Pleistocene Series/Epoch, and the Quaternary System/Period, at Monte San Nicola, Sicily, Italy $\left(37^{\circ} 8^{\prime} 45.64^{\prime \prime} \mathrm{N}, 14^{\circ} 12^{\prime} 15.22^{\prime \prime} \mathrm{E}\right.$; Figs. 1 and 2$)$, with a currently accepted age of 2.58 Ma (Gibbard and Head, 2009, 2010; Gibbard et al., 2010). It comprises the Gelasian Stage/Age (Rio et al., 1994, 1998) and the Calabrian Stage/Age (Cita et al., 2012).

When an SQS/ICS proposal to define the Upper/Late Pleistocene 
Table 1. Voting membership of the ICS Subcommission on Quaternary Stratigraphy in November, 2018

\begin{tabular}{|c|c|}
\hline Brent Alloway & School of Environment, The University of Auckland, Private Bag 92019, New Zealand \\
\hline Alan G. Beu & Paleontology Department, Institute of Geological \& Nuclear Sciences, P. O. Box 30368, Lower Hutt, New Zealand 5040 \\
\hline Kim M. Cohen & $\begin{array}{l}\text { Department of Physical Geography, Faculty of Geosciences, Utrecht University, P.O. BOX 80.115, } 3508 \text { TC Utrecht, } \\
\text { The Netherlands }\end{array}$ \\
\hline Philip L. Gibbard & Scott Polar Research Institute, University of Cambridge, Lensfield Road, Cambridge CB2 1ER, United Kingdom \\
\hline Martin J. Head (Chair) & Department of Earth Sciences, Brock University, 1812 Sir Isaac Brock Way, St. Catharines, Ontario L2S 3A1, Canada \\
\hline Karen Luise Knudsen & Department of Earth Sciences, University of Aarhus, C.F. Mollers Alle 120, DK-8000 Aarhus C, Denmark \\
\hline Thijs van Kolfschoten & Faculty of Archaeology, Leiden University, Reuvenplaats 4, 2300 RA, Leiden, The Netherlands \\
\hline Fabrizio Lirer & Istituto Ambiente Marino Costiero (IAMC)-CNR, Calata Porta di Massa, interno Porto di Napoli 80133, Napoli, Italy \\
\hline Thomas Litt & Institute of Paleontology, University of Bonn, Nussallee 8, D-53115 Bonn, Germany \\
\hline Jaiqi Liu & $\begin{array}{l}\text { Institute of Geology and Geophysics, Chinese Academy of Sciences, Beituchenglu, Qijiahuozhi, P.O. Box 9825, } \\
\text { Beijing 100029, China }\end{array}$ \\
\hline Leszek Marks & Polish Geological Institute, Rakowiecka 4, PL 00-975 Warsaw, Poland \\
\hline Jerry McManus & $\begin{array}{l}\text { Lamont-Doherty Earth Observatory, Columbia University, } 239 \text { Comer } 61 \text { Route 9W - PO Box 1000, Palisades, New } \\
\text { York 10964-8000, USA }\end{array}$ \\
\hline Brad Pillans (Vice-Chair) & Research School of Earth Sciences, The Australian National University, Acton, ACT, 2601, Australia \\
\hline Jan A. Piotrowski & Department of Earth Sciences, University of Aarhus, C.F. Moellers Alle 1120, DK-8000 Aarhus C, Denmark \\
\hline Matti Räsänen & Department of Geology, University of Turku, FIN-20014 Turun Yliopisto, Finland \\
\hline Sune Olander Rasmussen & Centre for Ice and Climate, Niels Bohr Institute, University of Copenhagen, Juliane Maries Vej 30, 2100 Copenhagen, Denmark \\
\hline Yoshiki Saito & Estuary Research Center (EsReC), Shimane University 1060, Nishikawatsu-cho, Matsue, 690-8504, Japan \\
\hline Alexey Tesakov & Geological Institute, Russian Academy of Sciences, Pyzhevsky, 7, 119017 Moscow, Russia \\
\hline Charles Turner & Department of Earth Sciences, The Open University, Milton Keynes MK7 6AA, United Kingdom \\
\hline Mike Walker & Department of Archaeology and Anthropology, University of Wales, Lampeter, Ceredigion, SA48 7ED, Wales, United Kingdom \\
\hline Jan A. Zalasiewicz (Secretary) & School of Geography, Geology and the Environment, University of Leicester, University Road, Leicester LE1 7RH, UK \\
\hline Caridad Zazo Cardeña & Departamento de Geologia, Museo Nacional de Ciencias Naturales (CSIC), Jose Gutierrez Abascal 28006-Madrid, Spain \\
\hline
\end{tabular}

(Gibbard, 2003; Head and Gibbard, 2015a) was denied ratification by the IUGS EC in 2008 partly on grounds that the rank of subseries/subepoch was not sanctioned for use on the International Chronostratigraphic Chart (Riccardi, 2008), it became clear to SQS that this would seriously hamper formal classification for the entire Quaternary (Head et al., 2017). Accordingly, when the Calabrian Stage was ratified in 2012, following the Gelasian as the second lowest stage of the Pleistocene, it had not been possible to propose simultaneously a Lower/ Early Pleistocene Subseries/Subepoch. Cita et al. (2012) nonetheless stated that "these two stages [Gelasian and Calabrian] together will comprise the Lower Pleistocene Subseries (Early Pleistocene Subepoch)." (Cita et al., 2012, p. 388). With the formal subdivision of the Holocene in 2018 (Walker et al., 2018), the rank of subseries/subepoch finally became available for use at least within the Quaternary System/Period. Ratification has now completed the task of formally uniting the Gelasian and Calabrian stages/ages to comprise the Lower Pleistocene Subseries/Subepoch.

The Gelasian Stage GSSP at Monte San Nicola is placed at the base of the marly layer immediately overlying a prominent sapropel known as the Nicola bed (Fig. 2). The Nicola bed is assigned to Mediterranean Precession-Related Sapropel (MPRS) 250, the midpoint of which has an astrochronological age of $2.588 \mathrm{Ma}$ (Lourens et al., 1996; Rio et al., 1998, p. 85). The GSSP is placed at the top of the Nicola bed, and assuming this sapropel represents a duration of 7-10 kyr and is fully preserved without burn-down at this locality, the age of the GSSP is therefore about 3.5-5.0 kyr younger than the midpoint age, rounding down to $2.58 \mathrm{Ma}$. That age is currently accepted (Gibbard and Head,
2009, 2010; Gibbard et al., 2010; Head and Gibbard, 2015a; Cohen et al., 2013). A foraminiferal isotope record is not currently available for Monte San Nicola, but the relative abundance pattern of the planktonic foraminifera Globigerinoides ruber, used here as a substitute for marine isotope stratigraphy, places the GSSP level within MIS 103 (Rio et al., 1998). The precise position and level of the GSSP cannot be ascertained from the Rio et al. study, but because the GSSP is placed at the top of a sapropel (see above), and given that sapropel midpoints in general are assumed to lag insolation maxima by around three thousand years or so (Rohling et al., 2015), the GSSP should occur within the earlier to middle part of MIS 103. The GSSP is located at the approximate level of the Gauss-Matuyama Chron boundary, the precise position of this reversal being unknown at Monte San Nicola (Head, 2019, contra Rio et al., 1998).

\section{Middle Pleistocene Subseries/Subepoch}

The Chibanian Stage/Age and Middle Pleistocene Subseries/Subepoch defined by a GSSP at the Chiba Section $\left(35^{\circ} 17^{\prime} 39.6^{\prime \prime} \mathrm{N}, 140^{\circ} 08^{\prime} 47.6^{\prime \prime} \mathrm{E}\right)$ in Japan was ratified by the IUGS EC on $17^{\text {th }}$ January, 2020 (Suganuma et al., this issue; Fig. 3). The GSSP is $1.1 \mathrm{~m}$ below the directional midpoint of the Matuyama-Brunhes paleomagnetic reversal (Okada et al., 2017), which is astronomically dated at $772.9 \mathrm{ka}$ (Suganuma et al., 2018), and is placed at the base of a regional lithostratigraphic marker, the Ontake-Byakubi E (Byk-E) tephra bed. The GSSP occurs just below the top of Marine Isotope Substage 19c and has an estimated astronomical age of $774.1 \mathrm{ka}$ (Suganuma et al., this issue) which is consist- 

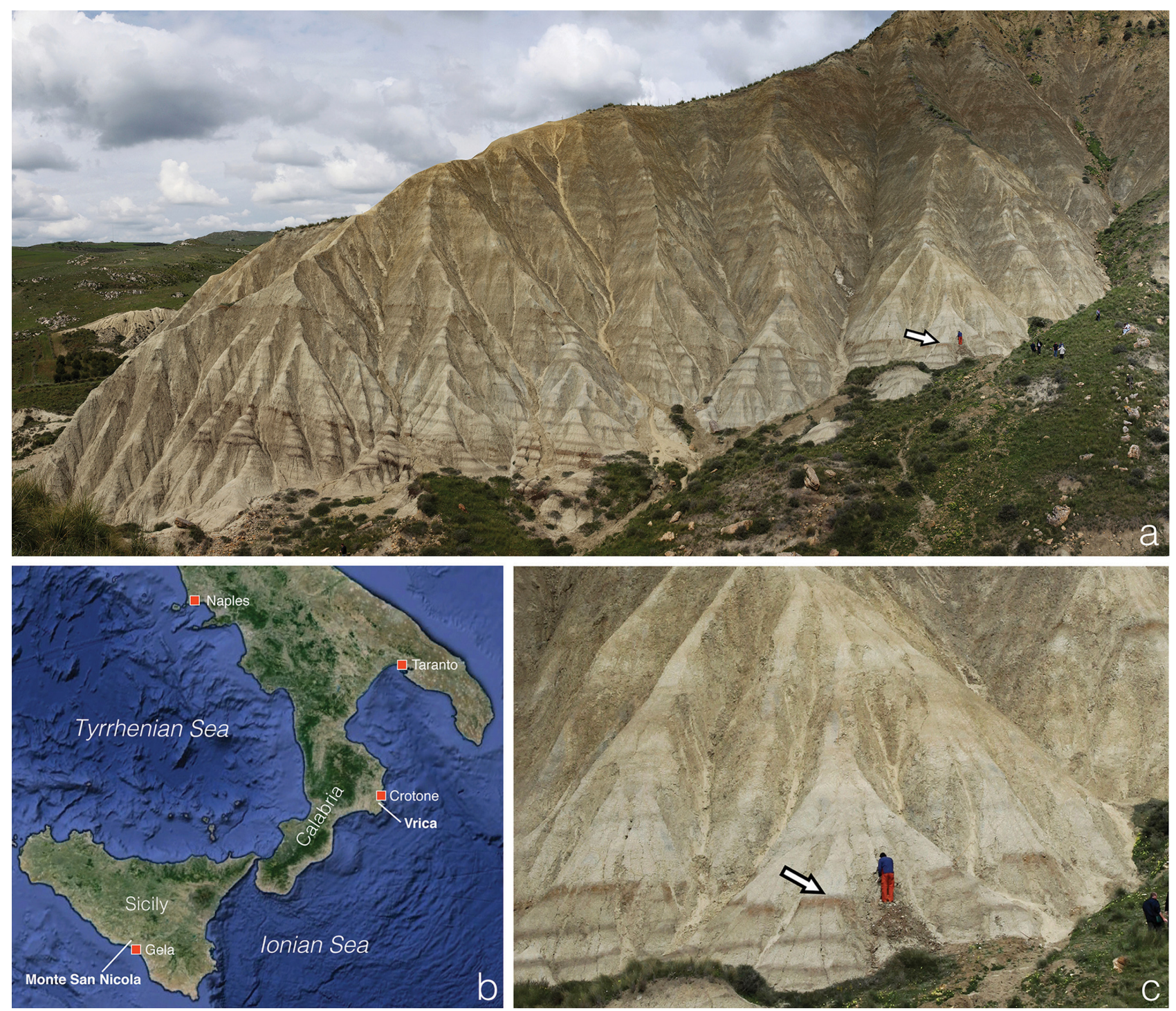

Figure 2. GSSP for the Gelasian Stage, Pleistocene Series, Quaternary System, and the newly ratified Lower Pleistocene Subseries. Panorama (a) and detail (c) of the Monte San Nicola section, showing the level of the GSSP (marked by an arrow) which is placed at the base of a marly layer overlying the prominent, sapropelic Nicola bed. Photographs kindly supplied by John Clague. The location of Monte San Nicola (b) is also given.

ent with a U-Pb zircon age of $772.7 \pm 7.2 \mathrm{ka}$ for the eruption/deposition age of the Byk-E tephra (Suganuma et al., 2015).

This placement follows established tradition of using the MatuyamaBrunhes paleomagnetic boundary to define the base of the Middle Pleistocene (Pillans, 2003; Head and Gibbard, 2015a, b), following the recommendations of Butzer and Isaac (1975) and the INQUA Working Group on Major Subdivision of the Pleistocene made at the 12th INQUA Congress in Ottawa in 1987 (Richmond, 1996). In 2004 at the 32nd International Geological Congress in Florence in 2004, the SQS Early-Middle Pleistocene Boundary Working Group adopted this paleomagnetic reversal as the primary guide for the boundary (Head et al., 2008).

\section{Upper/Late Pleistocene Subseries/Subepoch}

The terms Upper/Late Pleistocene at the rank of subseries/subep- och are now ratified in name only, pending definition by a GSSP, but with a provisional age of $\sim 129 \mathrm{ka}$ (Fig. 1) relating to significant warming at the beginning of the Last Interglacial (Head, 2019).

During the Leningrad Conference in 1932 it had been decided that the base of the Upper Pleistocene should coincide with the base of the Last Interglacial (the Eemian regional Stage in Europe). At the 12th INQUA Congress in Ottawa in 1987, a proposal was approved to use the base of MIS 5 (Termination II) as the primary guide for the boundary (Anonymous, 1988; Richmond, 1996). The events based on these proposals are now known to be not precisely synchronous, the onset of the Eemian regional Stage off Portugal lagging the inception of MIS 5 by about six thousand years (Shackleton et al., 2003), although it is significant that both proposals reference the Last Interglacial. There are currently two potential candidates for the GSSP, the Fronte section, Taranto, Italy (Negri et al., 2015) and the EPICA Dome C Antarctic ice core (Head and Gibbard, 2015a; Head, 2019). 


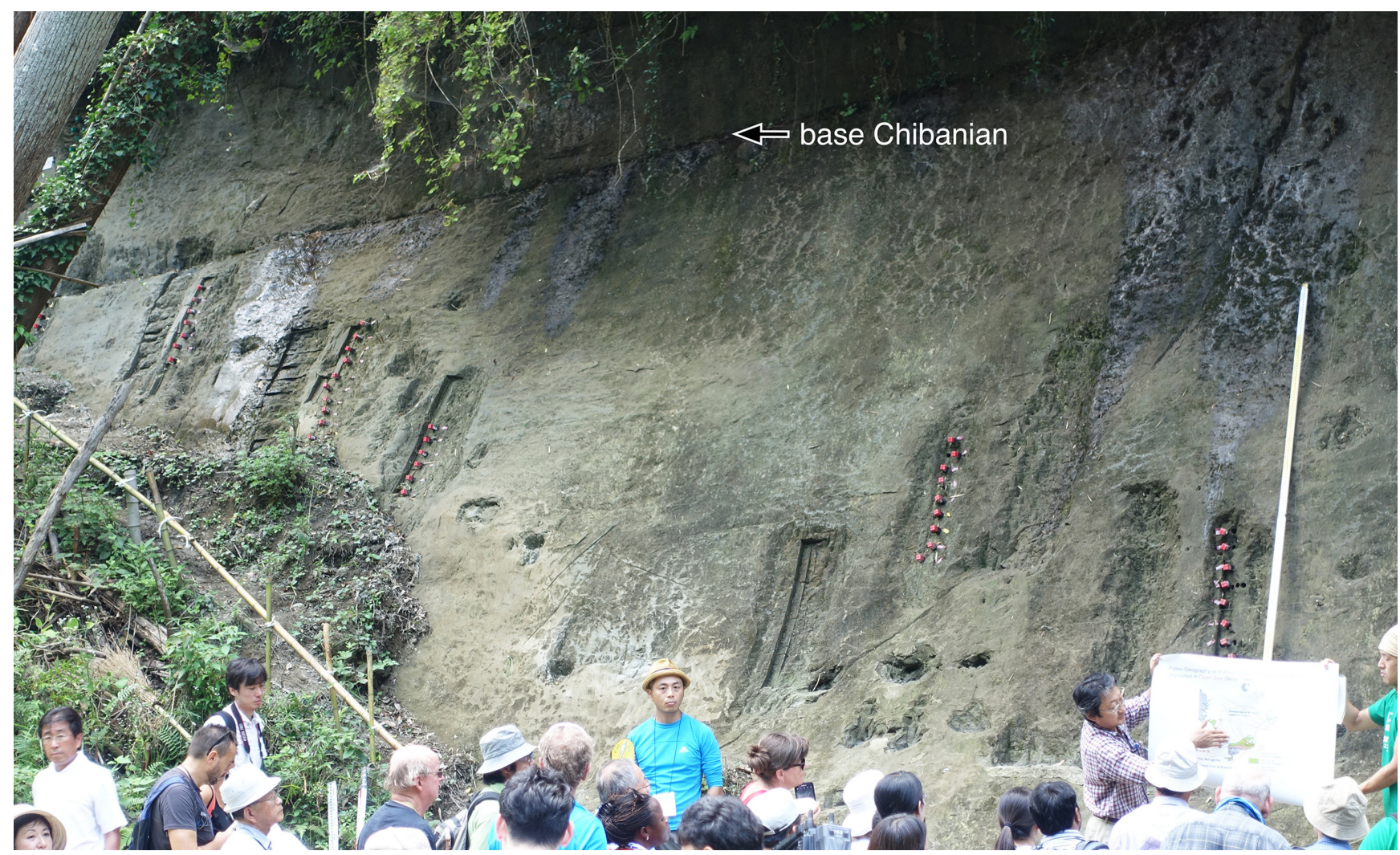

Figure 3. Chiba section, Japan: site of the GSSP for the now ratified Chibanian Stage and Middle Pleistocene Subseries. The marker bed for the GSSP is the Ontake-Byakubi-E (Byk-E) tephra bed (indicated by an arrow) which is $1.1 \mathrm{~m}$ below the directional midpoint of the Matuyama-Brunhes paleomagnetic boundary. This reversal serves as the primary guide to the Lower-Middle Pleistocene boundary, allowing its global recognition. Photograph by MJH taken at the INQUA Post-Congress field trip, August 2015.

\section{Colour Coding of New Units}

Each chronostratigraphic unit on the ICS International Chronostratigraphic Chart (Cohen et al., 2013) can be identified by a unique colour following a scheme developed by the Commission for the Geological Map of the World (CGMW). This scheme uses colour codes both in CMYK and RGB, and the International Chronostratigraphic Chart labelled with these codes is available from the CGMW website (www.ccgm.org). CMYK is employed in colour printing, and the CGMW uses this model as the primary reference system in defining its official colours. RGB nonetheless has become increasingly popular owing in part to its compatibility with online publishing. Converting CMYK to RGB is not straightforward and is affected by colour management settings chosen by the user in their computer graphics program. The CGMW converts CMYK to RGB values using the "Emulate Adobe Illustrator 6.0" color function in Adobe ${ }^{\circledR}$ Illustrator $^{\circledR}$. The present paper (Fig. 1) follows the CGMW scheme which was updated in September, 2020 to provide colours for the recently ratified subdivisions of the Pleistocene and Holocene (B. Vrielynck, written communication to MJH, 14 September, 2020; Table 2). This revision included new colours for the Pleistocene and Holocene series.
Table 2. CMYK and RGB colour codes for the Quaternary and its subdivision (Fig. 1) as adopted by the Commission for the Geological Map of the World (CGMW). New colour codes introduced by the CGMW in September 2020 are in italics. Earlier colour codes that have not been superseded are in roman type. The CGMW defines its colours by CMYK codes; their RGB equivalents are for information only

\begin{tabular}{lcc}
\hline \hline & CMYK & RGB \\
\hline Quaternary System & $0 / 0 / 50 / 0$ & $249 / 249 / 127$ \\
Pleistocene Series & $0 / 5 / 40 / 0$ & $255 / 239 / 175$ \\
Lower Pleistocene Subseries & $0 / 5 / 35 / 0$ & $255 / 240 / 185$ \\
Gelasian Stage & $0 / 5 / 30 / 0$ & $255 / 237 / 179$ \\
Calabrian Stage & $0 / 5 / 25 / 0$ & $255 / 242 / 186$ \\
Middle Pleistocene Subseries & $0 / 5 / 20 / 0$ & $255 / 242 / 199$ \\
Chibanian Stage & $0 / 5 / 20 / 0$ & $255 / 242 / 199$ \\
Upper Pleistocene Subseries & $0 / 5 / 15 / 0$ & $255 / 242 / 211$ \\
Fourth stage & $0 / 5 / 15 / 0$ & $255 / 242 / 211$ \\
Holocene Series & $0 / 10 / 20 / 0$ & $254 / 235 / 210$ \\
Lower Holocene Subseries & $0 / 10 / 15 / 0$ & $254 / 236 / 219$ \\
Greenlandian Stage & $0 / 10 / 15 / 0$ & $254 / 236 / 219$ \\
Middle Holocene Subseries & $0 / 10 / 10 / 0$ & $253 / 236 / 228$ \\
Northgrippian Stage & $0 / 10 / 10 / 0$ & $253 / 236 / 228$ \\
Upper Holocene Subseries & $0 / 10 / 5 / 0$ & $253 / 237 / 236$ \\
Meghalayan Stage & $0 / 10 / 5 / 0$ & $253 / 237 / 236$ \\
\hline
\end{tabular}




\section{Conclusions}

The ratified proposals have overwhelming support within the Quaternary community and are strongly endorsed by INQUA (Head et al., 2017; van Kolfschoten, 2020). The terms Lower/Early Pleistocene are now officially available for deposits, events, or transitions that cannot be assigned to a specific (Gelasian or Calabrian) stage. The Chibanian Stage and Middle Pleistocene Subseries/Subepoch result from a simultaneous proposal also recently ratified (Suganuma et al., this issue). The Upper/Late Pleistocene Subseries/Subepoch is ratified in name only, to complete the formal tripartite subdivision of the Pleistocene. Progress on its definition by GSSP, with a corresponding stage, is being made within the Upper Pleistocene Working Group of the SQS.

The Quaternary community uses geochronological terms (Early/ Middle/Late) as a natural consequence of displaying geological data against age rather than depth. Such terms are employed widely and with considerable frequency. For example, the term "Late Pleistocene" has been cited in 16,997 publications according to Clarivate's Web of Science, searched on February 2, 2020, as compared with the term "Silurian" searched at the same time and cited in 8,268 publications. The official recognition of these subseries/subepoch terms, with their long history and wide use, increases their value to the community. Pleistocene subseries/subepoch terminology is now brought in line with that of the Holocene, effecting standardization for the entire Quaternary. This also resolves the editorial quandary of capitalization (Head et al., 2017): an uppercased initial letter is now required unequivocally for subseries/subepoch terms throughout the Quaternary.

\section{Acknowledgements}

We are grateful to many colleagues for helpful discussions and assistance, including Dave Harper as Chair of the ICS, and Stan Finney as Secretary-General of the IUGS. Phil Gibbard and an anonymous reviewer kindly provided very helpful comments on the manuscript. We appreciate discussions with Gabi and Jim Ogg on timescale colour codes, and Bruno Vrielynck for helpfully providing the CGMW codes given in Table 2. MJH acknowledges support from a Natural Sciences and Engineering Research Council of Canada Discovery Grant.

\section{References}

Aguirre, E., and Pasini, G., 1985, The Pliocene-Pleistocene boundary. Episodes, v. 8, pp. 116-120.

Anonymous, 1988, Biostratigraphy rejected for Pleistocene subdivisions. Episodes, v. 11, p. 228.

Aubry, M.-P., 2016, Cenozoic chronostratigraphic terminology: In defense of formal subseries. Stratigraphy, v. 13, pp. 1-20.

Butzer, K.W., and Isaac, G.L. (Eds.), 1975, After the Australopithecines. Mouton, The Hague, 911 pp.

Cita, M.B., Gibbard, P.L., Head, M.J., and The Subcommission on Quaternary Stratigraphy, 2012, Formal ratification of the base Calabrian Stage GSSP (Pleistocene Series, Quaternary System). Episodes, v. 35, pp. 388-397.

Cohen, K.M., Finney, S.C., Gibbard, P.L., and Fan, J.-X., 2013, The ICS International Chronostratigraphic Chart. Episodes, v. 36, pp. 199-204 [v. 2020/01; updated, January 2020].

Gaudenyi, T., Nenadić, D., Jovanović, M., and Bogićević, K., 2014, The stratigraphical position and the use of the term Eopleistocene in Serbian geological literature. Quaternary International, v. 319, pp. 150-159.

Gibbard, P.L., 2003, Definition of the Middle-Upper Pleistocene boundary. Global and Planetary Change, v. 36, pp. 201-208.

Gibbard, P.L., and Head, M.J., 2009, IUGS ratification of the Quaternary System/Period and the Pleistocene Series/Epoch with a base at 2.58 Ma. Quaternaire, v. 20, pp. 411-412.

Gibbard, P.L., and Head, M.J., 2010, The newly-ratified definition of the Quaternary System/Period and redefinition of the Pleistocene Series/ Epoch, and comparison of proposals advanced prior to formal ratification. Episodes, v. 33, 152-158.

Gibbard, P.L., Head, M.J., Walker, M.J.C. and The Subcommission on Quaternary Stratigraphy, 2010, Formal ratification of the Quaternary System/Period and the Pleistocene Series/Epoch with a base at 2.58 Ma. Journal of Quaternary Science, v. 25, pp. 96-102.

Gromov, V.I., 1939, Brief systematic and stratigraphic review of Quaternary mammals of the USSR (To Academican V.A. Obuchev in commemoration on the 50th anniversary of scientific and pedagogical activity). II. In: Akademiku, V.A. (Ed.), Obruchevu k pyatidesyatiletiyu nauchnoi pedagogicheskoi deyatel'nosti. Akad. Nauk. SSSR, Moscow-Leningrad, pp. 163-223.

Hopwood, A.T., 1935, Fossil elephants and Man. Proceedings of the Geologists' Association, v. 46, pp. 46-60.

Head, M.J., Pillans, B., and Farquhar, S., 2008, The Early-Middle Pleistocene Transition: characterization and proposed guide for the defining boundary. Episodes, v. 31, pp. 255-259.

Head, M.J., and Gibbard, P.L., 2015a, Formal subdivision of the Quaternary System/Period: Past, present, and future. Quaternary International, v. 383, pp. 4-35.

Head, M.J., and Gibbard, P.L, 2015b, Early-Middle Pleistocene transitions: linking terrestrial and marine realms. Quaternary International, v. 389, pp. 7-46.

Head, M.J., Aubry, M.-P., Walker, M., Miller, K.G., and Pratt, B.R., 2017, A case for formalizing subseries (subepochs) of the Cenozoic Era. Episodes, v. 40, pp. $22-27$.

Head, M.J., 2019, Formal subdivision of the Quaternary System/Period: present status and future directions. Quaternary International, v. 500, pp. 32-51.

Head, M.J., 2020, Review of the Early-Middle Pleistocene boundary and Marine Isotope Stage 19. Progress in Earth and Planetary Science (in revision).

Lourens, L.J., Antonarakou, A., Hilgen, F.J., Van Hoof, A.A.M, VergnaudGrazzini, C., and Zachariasse, W.J., 1996, Evaluation of the Plio-Pleistocene astronomical timescale. Paleoceanography, v. 11, pp. 391-413.

Lyell, C., 1839, Nouveaux eléménts de géologie. Pitois-Levrault and Co., Paris, i-xxvii+1-648 p.

Lyell, C., 1873. The Geological Evidences of the Antiquity of Man, fourth ed. J. Murray, London. 572 pp.

Negri, A., Amorosi, A., Antonioli, F., Bertini, A., Florindo, F., Lurcock, P.C., Marabini, S., Mastronuzzi, G., Regattieri, E., Rossi, V., Scarponi, D., Taviani, M., Zanchetta, G., and Vai, G.B., 2015, A potential global boundary stratotype section and point (GSSP) for the Tarentian Stage, Upper Pleistocene, from the Taranto area (Italy): Results and future perspectives. Quaternary International, v. 383, pp. 145-157.

Nikiforova, K.V., 1987, The boundaries of the Eopleistocene. International Geology Review, v. 29, pp. 1265-1280.

Okada, M., Suganuma, Y., Haneda, Y., and Kazaoka, O., 2017, Paleomagnetic direction and paleointensity variations during the MatuyamaeBrunhes polarity transition from a marine succession in the Chiba composite section of the Boso Peninsula, central Japan. Earth, Planets, Space, v. 69, doi.org/10.1186/s40623-017- 0627-1

Pillans, B., 2003, Subdividing the Pleistocene using the Matuyama-Brunhes boundary (MBB): an Australasian perspective. Quaternary Science 
Reviews, v. 22, pp. 1569-1577.

Pillans, B., and Gibbard, P.L., 2012, Chapter 10. The Quaternary Period. In: Gradstein, F.M., Ogg, J.G., Schmitz, M., and Ogg, G. (eds.), The Geologic Time Scale 2012. Elsevier, Amsterdam.

Riccardi, A.C., 2008, Unpublished letter to Dr Stanley Finney, Chairman, International Commission on Stratigraphy. Two pages. Dated 22 September, 2008. [A.C. Riccardi was then President of the IUGS].

Richmond, G.M., 1996, The INQUA-approved provisional Lower-Middle Pleistocene boundary. In: Turner, C. (Ed.), The Early Middle Pleistocene in Europe. Balkema, Rotterdam, pp. 319-326.

Rio, D., Sprovieri, R., and Di Stefano, E., 1994, The Gelasian Stage: a proposal of a new chronostratigraphic unit of the Pliocene Series. Rivista Italiana di Paleontologia e Stratigrafia, v. 100, pp. 103-124.

Rio, D., Sprovieri, R., Castradori, D., and Di Stefano, E., 1998, The Gelasian Stage (Upper Pliocene): a new unit of the global standard chronostratigraphic scale. Episodes, v. 21, pp. 82-87.

Rohling, E.J., Marino, G., and Grant, K.M., 2015, Mediterranean climate and oceanography, and the periodic development of anoxic events (sapropels). Earth-Science Reviews, v. 143, pp. 62-97.

Shackleton, N.J., Sánchez-Goñi, M.F., Pailler, D., and Lancelot, Y., 2003, Marine Isotope Substage 5e and the Eemian Interglacial. Global and Planetary Change, v. 36, pp. 151-155.

Suganuma, Y., Okada, M., Horie, K., Kaiden, H., Takehara, M., Senda, R., Kimura, J., Haneda, Y., Kawamura, K., Kazaoka, O., and Head, M.J., 2015, Age of Matuyama-Brunhes boundary constrained by U-Pb zircon dating of a widespread tephra. Geology, v. 43, pp. 491-494.

Suganuma, Y., Haneda, Y., Kameo, K., Kubota, Y., Hayashi, H., Itaki, T., Okuda, M., Head, M.J., Sugaya, M., Nakazato, H., Igarashi, A., Shikoku, K., Hongo, M., Watanabe, M., Satoguch, Y., Takeshita, Y., Nishida, N., Izumi, K., Kawamura, K., Kawamata, M., Okuno, J., Yoshida, T., Ogitsu, I., Yabusaki, H., and Okada, M., 2018, Paleoclimatic and paleoceanographic records through Marine Isotope Stage 19 at the Chiba composite section, central Japan: A key reference for the Early-Middle Pleistocene Subseries boundary. Quaternary Science Reviews, v. 191, pp. 406-430.

Suganuma, Y., Okada, M., Head, M.J., Kameo, K., Haneda, Y., Hayashi,
H., Irizuki, T., Itaki, T., Izumi, K., Kubota, Y., Nakazato, H., Nishida, N., Okuda, M., Satoguchi, Y., Simon, Q., and Takeshita, Y. Accepted. Formal ratification of the Global Boundary Stratotype Section and Point (GSSP) for the Chibanian Stage and Middle Pleistocene Subseries of the Quaternary System: the Chiba Section, Japan. Episodes, this issue.

Tesakov, A.S., Shik, S.M., Velichko, A.A., Gladenkov, Yu.B., Lavrushin, Yu.A., and Yanina, T.A., 2015, Proposed changes in the stratigraphic structure of the Quaternary for the General Stratigraphic Scale of Russia. In: Proceedings of the All-Russian Scientific Meeting "Stratigraphic and Paleogeographic Problems of the Neogene and Quaternary of Russia (new materials and methods)". GEOS, 2015 (Moscow), pp. 57-59. van Kolfschoten, T., 2020, Unpublished letter from Thijs van Kolfschoten as President of INQUA to Prof. Qiuming Cheng as President of IUGS. Dated $21^{\text {st }}$ January, 2020. One page.

Walker, M., Head, M.J., Berkelhammer, M., Björck, S., Cheng, H., Cwynar, L., Fisher, D., Gkinis, V., Long, A., Lowe, J., Newnham, R., Rasmussen, S., and Weiss, H., 2018, Formal ratification of the subdivision of the Holocene Series/Epoch (Quaternary System/Period): two new Global Boundary Stratotype Sections and Points (GSSPs) and three new stages/ subseries. Episodes, v. 41, pp. 213-223.

Walker, M., Head, M.J., Berkelhammer, M., Björck, S., Cheng, H., Cwynar, L., Fisher, D., Gkinis, V., Long, A., Lowe, J., Newnham, R., Rasmussen, S., and Weiss, H., 2019, Subdividing the Holocene Series/Epoch: formalisation of stages/ages and subseries/subepochs, and designation of GSSPs and auxiliary stratotypes. Journal of Quaternary Science, v. 34, pp. 173-186.

Woldstedt, P., 1953, Über die Benennung einiger Unterabteilungen des Pleistozäns. Eiszeitalter und Gegenwart, v. 3, pp. 14-18.

Zeuner, F.E., 1935, The Pleistocene chronology of Central Europe. Geological Magazine, v. 72 , pp. 350-376.

Zeuner, F.E., 1945, The Pleistocene Period: Its climate, chronology and faunal successions. Ray Society, London, vol. 130, pp. i-xii+1-322.

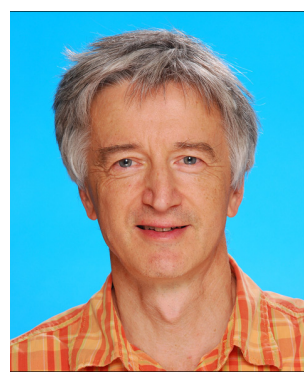

Jan Zalasiewicz is Emeritus Professor of Palaeobiology at the University of Leicester, UK, having formerly worked as a field geologist and biostratigrapher at the British Geological Survey. He is Chair of the International Subcommission on Quaternary Stratigraphy (SQS) (2020-), having served as SQS Secretary (2012-2020). He has also served as Chair of the SQS Working Group on the Anthropocene (2009-2020), as Vice-Chair of the International Subcommission on Stratigraphic Classification (2008-2016), and as Secretary, then Chair, of the Stratigraphy Commission of the Geological Society of London. He has worked on the stratigraphy and sedimentology of mainly Early Palaeozoic and Quaternary terrains.

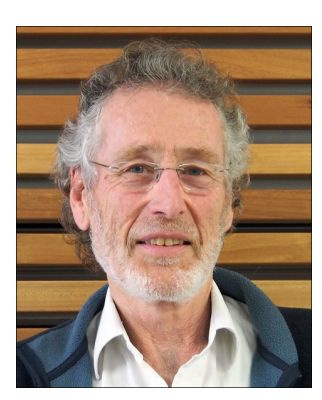

Brad Pillans is an Emeritus Professor in the Research School of Earth Sciences at The Australian National University in Australia. $\mathrm{He}$ is a voting member of the International Subcommission on Quaternary Stratigraphy (SQS), having served as Vice-Chair (20122020), and Co-Convenor of the SQS Working Group on the Lower-Middle Pleistocene Subseries Boundary (2010-2020). He was President of the INQUA Stratigraphy \& Chronology Commission (2003-2011) and President of the Geological Society of Australia (2010 2012). His interests include Quaternary stratigraphy, geochronology, geomorphology, and regolith geology. 